\title{
Building the Politics of the Law of Protection of Well-Known Drug Brands in Indonesia
}

\author{
Doddy Kridasaksana ${ }^{1}$, Budi Santoso ${ }^{2}$, Kholis Roisah ${ }^{3}$ \\ ${ }^{1}$ Doctoral Student, Diponegoro University and Lecturer Semarang University, Indonesia, \\ ${ }_{2}^{2}$ Professors Diponegoro University, Indonesia, ${ }^{3}$ ProfessorsDiponegoro University, Indonesia
}

\begin{abstract}
Introduction: Utilization of well-known drug brands in bad faith at this time is increasingly rampant and leads to losses to both consumers and owners of such well-known brands.

Research Objective: The purpose of this study is to analyze and find the political formulation of the law of protection of well-known drug brands from the act of passing off in Indonesia.

Research Method: This research uses a normative juridical research approach because it seeks to examine the legal politics related to Law Number 20 of 2016 on Brand and Geographical Indications.

Research Results: Protection of well-known drug brands in Indonesia based on Law Number 20 of 2016 on Brand and Geographical Indications, consisting of brand scope, actual use, nature of goods, announcements, rights granted, application requirements to obtain brand certificates, transfer and licenses, and brand registration. The politics of the protection of well-known drug brands in the future, that in accommodating the passing off of well-known drug brands in Indonesia, it is necessary to protect holders of well-known brand rights in Indonesia.
\end{abstract}

Keywords: Legal Protection; Political Law; Famous Drug Brands.

\section{Introduction}

In the face of free markets, Indonesia needs various implementations as an action to carry out the plan that has been made. One of the implementations of The Indonesian state and society towards the 2020 freemarket era is to become a free open market for goods and services both intellectual creativity of individuals and foreign companies. The trend of increasing trade in goods and services will continue in line with the increasing national economic growth. Like other human intellectual goods and creativity, it is necessary to acknowledge and reward the legal order called intellectual property law. One form of intellectual property rights is a brand

\footnotetext{
Corresponding Authors:

Doddy Kridasaksana

Faculty of Law Semarang University, Arteri SoekarnoHatta Street, Semarang City, Indonesia

e-mail: doddykridasaksana4@gmail.com
}

specifically regulated in Law Number 20 of 2016 on Brand and Geographical Indications ${ }^{1}$.

The use of well-known brands in bad faith at this time is increasingly rampant and leads to losses to both consumers and owners of such well-known brands. The success and high reputation of a company with products and also brands attached to the product often tempts other parties who have bad intentions to deal with in ways that violate business ethics, norms of decency, and the law ${ }^{2}$.

Acts that try to gain profit by brand-blocking so that it can cause deception, misdeeds, or violations of the brand as above is known as passing off. Passing off over a well-known brand today can only be said to be a reputational hitch that leads to fraudulent competition conducted by irresponsible manufacturers ${ }^{3}$. The form of passing off action can give an idea, among others, the likelihood of confusion, mistake, or deception, namely there is a form of a brand that resembles or has similarities with well-known brands. 
The problem that is often encountered in IPR, especially in the field of brands is the emergence of unhealthy business competition. Basically, with Indonesia's participation in the WTO which includes the TRIPs Agreement, it indirectly means agreeing to a world competition plan in the framework of free trade. One of the consequences of participation is how to prepare businesses in Indonesia to be able to conduct business competition honestly and healthily in the global market. This can only be realized if the government can provide a sense of fairness and legal certainty to unhealthy business competition practices ${ }^{4}$. Unhealthy business competition practices have had widespread impacts in various fields, including imported drugs. This is a very concerning issue considering the provision of drugs is one of the efforts of public health services. Everyone has the right to a level of life that ensures health and good health for himself and his family, including food, clothing, boards, and health services as well as necessary social enterprises, and is entitled to guarantees at a time of unemployment, illness, disability, widows/widowers, the elderly or experiencing other lack of living because of circumstances beyond his control.

An example of a well-known drug brand dispute case is between PT. LAPI and PT. GRAHA FAJAR FARMACEUTICALLABORATORIES. PT. LAPI which has the trademark "LAMESON" with Trademark IDM000234288 (Extension of Number471636) for the type of goods: "Pharmacy preparations, ingredients for hand-feeding/diet tailored for medical use, healthy food/food supplement and herbs" which belongs to the class 5 that filed a lawsuit against PT. GRAHA FAJAR FARMACEUTICALLABORATORIES which has a trademark "FLAMESON" with the number IDM00008448 for the type of goods: "Cleaning cotton, plasters and adhesive tapes for medical purposes, odor removal/neutralizer preparations, air fresheners and air purifiers, anti-parasitic preparations, anti-septic cotton, anti-septic, sterile cotton, medium for bacterial breeding, Hygienic pads, sanitary napkins, wound dressings, blood for medical purposes, blood plasma, camphor and camphor oil for medical purposes, deodorant other than for personal use, sanitary napkins for hygiene purposes, sanitary pads for medicine and surgery, fungal dressings, gases for medical purposes, gauze to bandage, diapers or pants for people who are powerless to withstand urination or large, carbolic, fuel and liquid mosquito repellents, insect repellents, exterminators (materials), disinfectants (ingredients), flea repellents (germs), moss exterminator (material), bandages, insect repellent preparations, preparations to eradicate destructive animals, preparations to eradicate bad plants" which also belong to class 5 .

The laws governing passing off specifically in Indonesia to date do not exist because Indonesia adheres to the Civil Law legal system. This legal system uses basic divisions into civil law and public law, both of which are not known in the common law system. Directorate General of Intellectual Property Rights only handles passing off cases that indicate a violation of a brand that has a good intention, such as an equation in essence or whole (using a certain form, look (packaging), or design or logo of a particular brand. Therefore, it is important to make a study on the legal politics of drug brand protection in Indonesia.

Given the study of the politics of law leads to law enforcement, in particular protecting IPR, in this case, well-known brands from brand violations including passing off actions, then it should be legal politics to enforce the protection of well-known brands against the act of passing off against the community needs to be realized. From the above problems, the purpose of this research is to analyze and find the political formulation of the law of protection of well-known drug brands from the act of passing off in Indonesia.

\section{Research Methodology}

The research approach that will be used in this research is the normative juridical approach, which is carried out based on the main legal materials ${ }^{5}$, which include ways to study the theories, concepts, legal principles, and laws and regulations related to this research ${ }^{6}$. Also, the use of normative juridical approaches related to the purpose of the study that seeks to examine the politics of law relating to Law Number 20 of 2016 on Brand and Geographical Indications along with regulations related to the law related to the act of passing off, such as impersonation or denotation of the reputation of well-known drug packaging that has the insecurity of packaging impersonation.

\section{Discussion}

According to Article 1 of Law Number 36 of 2009 , that drug is an ingredient or alloy of ingredients, including biological products used to influence or investigate the physiological system or state of pathology in the determination of diagnosis, prevention, healing, 
recovery, improvement of health and contraceptives for humans.

By the Regulation of the Minister of Health of the Republic of Indonesia Number 917/MENKES/ PER/X/1993 concerning Mandatory List of Finished Drugs in Article 1 Part 3 that drugs can be grouped into several groups. Classification intended for increased safety and provision of use and security of distribution consisting of over-the-world drugs, limited over-theworld drugs, mandatory drug pharmacies, hard drugs, psychotropics, and narcotics?

Included in the group above are drugs made with chemicals and/or with materials from plant and animal elements that have been categorized as medicinal ingredients or mixtures/alloys both, so that in the form of synthetic drugs and semi-synthetic drugs, respectively. Herbal medicine/traditional (TR) is not included in this group.

Classification of drugs based on marking on the packaging of the drug consists of First is an over-theworld drug can be purchased freely without a prescription and can be purchased at pharmacies and licensed drug stores to overcome (minor illnesses) that are nonspecific. Over-the-top medicine is relatively safe, can be used to deal with mild symptomatic diseases that are widely suffered by the general public whose treatment can be done alone by the sufferer or self-medication (selftreatment or self-medication). The drug has been used in scientific (modern) drug and is shown to have no risk of alarming harm. Marking on the packaging: dot a green circle with a black border. Examples: Oralite, some analgetic or pain killer (painkillers) and some antipyretics (heat-lowering drugs) such as paracetamol, ibuprofen, aceosal (aspirin), some vitamin and mineral supplements/multivitamins such as vitamin $\mathrm{C}$, and vitamin B complex, antacid DOEN, eucalyptus oil, liniment, outer wound medicine, and so on.

Second, is a limited over-the-free drug also called drug list $\mathrm{W}$ (W: Waarschuwing= warning/alert) is a hard drug that can be purchased without a doctor's prescription but its use should pay attention to the drug information on the packaging. In the sale has a limit on the amount and content level must be accompanied by a warning sign, warning P1 - P6. Restricted can only be purchased at pharmacies or licensed drugstores. Restricted over-the-world drugs are relatively safe as long as they comply with the rules of use.
Third, is hard drugs (Drug list G or "Gevaarlijk", dangerous) including also psychotropics to obtain it must be by prescription and can be purchased at a pharmacy or hospital. However, there are hard drugs that can be bought in pharmacies without a doctor's prescription that is handed over by pharmacists called Mandatory Medicine Pharmacy (OWA) such as linestrenol, antacids, salbutamol, bacitracin cream, ranitidine, and others.

All types of drugs require a brand in the process of trading. Brands distinguish products from competitor's products. The brand will provide identification that a product different from other products. Product identification is also useful when sending and promotions. Adding value to the product, consumers see the brand as a benchmark and add value to a product. Brands can add an image of a product. Consumers also tend to choose branded products because more trustworthy, the origin of the product can be shrinking. The need to manage the brand will be more felt by Small Business entrepreneurs who will open branches. The brand is part of intellectual property rights.

The term Intellectual Property Rights (IPR) was first used in 1790, then in 1793. Fichte says the creator's property rights are in his book. The property in question is not a book as an object, but a book in the sense of its contents. The term IPR consists of three keywords, namely Rights, Property, and Intellectual ${ }^{8}$. Wealth is an abstraction that can be owned, transferred, bought, or sold. Intellectual Property is the property of all the production of intelligence of thought, such as technology, knowledge, art, literature, song composition, writing, caricature, and so on. IPR is also the right, authority, or power to do something about such intellectual property, leading to the politics of the law (leading to the regulation of applicable norms or laws).

So far there are still various opinions including the mention of the term IPR with Intellectual Property Rights/ Hak Milik Intelektual (HMI). One of them is William Fisher who concluded that there are four approaches related to the regulation of Intellectual Property Rights, including; that the regulation of property rights should be maximized for the welfare of many communities thereby should be optimized the balance between the power of exclusive rights that creators have to encourage creation and discovery, as well as the right of the public to acquire or enjoy a creation ${ }^{9}$. This view was influenced by utilitarians Jeremy Bentham and John Stuart Mill. Furthermore, this view was developed by Posner in the 
theory of economic analysis of law (theory of economic analysis of law). This theory is a new theory that has an impact on civil law adherents such as Indonesian law. Through economic principles, Posner hopes to improve legal efficiency including efficiency in improving social welfare (social welfare). In the principle of efficiency, Posner emphasizes "pareto improvement" where the purpose of the legal arrangement can provide valuable input for justice and social welfare. According to Posner sees an optimistic future and believes that judges can create good law/liberal law if they diligently adore social change and external changes with a clear goal, namely the efficiency of the judge's ruling ${ }^{10}$. Furthermore, the depiction of economic viewpoints on the law gave birth to the behavior of law and economy. This behavioral principle is applied in a plural society, which is impossible to avoid transaction fees. The impact of the rule of law is one of the musts that can provide legal certainty and maintain a sense of social justice in society. These rules can be in the form of contracts and arrangements regarding the limits of ownership and property rights directed at achieving social welfare ${ }^{11}$. This view is based on the proposition that a person who has struggled to pour all his abilities or expertise to create something is naturally entitled to his efforts. This approach is derived from Kant and Hegel's writings which state that individual property rights are crucial in providing a sense of satisfaction in some human needs. This approach is based on the proportion that property rights in general and intellectual property rights in particular, can and should be established to help promote the achievement of justice and attractive culture.

The development of IPR, one of which is the Brand, until now has not been encouraging, for example, seen from the rampant violations, especially against wellknown Brands. Explanation of the Brand is certainly inseparable from goods and services in commodity trading. Commodity trading characterized by the existence of a Brand certainly has a selling value that economically can help the income of the community, individuals, or legal entities in obtaining profit. Traded brands have a variety of shapes and advantages to attract consumers interested in buying them.

The establishment of IPR law, especially the Brand is sought to remain oriented to the interests of the national IPR, although the provisions of Trade-Related Aspects of Intellectual Property Rights (TRIPs) cannot be ignored. TRIPs are an instrument of international law, although TRIPs are not the starting point for the concept of intellectual property rights. Various International Conventions have long been born, and have been changed several times. The main and also significant basis of the concept of Industrial Property is the Paris Convention for the Protection of Industrial Property (Paris Convention).

TRIPs contain four groups of settings. First, that associates Intellectual Property Rights with the concept of international trade. Second, which requires member states to comply with the Paris Convention. Third, set your own rules or conditions. Fourth, which is a provision for things that generally include law enforcement efforts contained in the legislation of member states. Indonesia's newest Brand Law, namely Law Number 20 of 2016 on Brand and Geographical Indications as a modifier of the old Brand Law (Law Number 19 of 1992 on Brands amended into Law Number 14 of 1997 on Brands then changed again to Law Number 15 of 2001 on Brands) has adopted the provisions of trips. The provisions of trips as outlined in the contents of Law Number 20 of 2016 on Brand and Geographical Indications are as follows:

1. Scope: The brand includes brands and geographical indications (article 2 paragraph (1)), which are protected consisting of signs in the form of images, logos, names, words, letters, numbers, color arrangements, in the form of two dimensions and/ or 3 (three) dimensions, sounds, holograms, or a combination of two or more elements to distinguish goods and/or services produced by people or legal entities in the activities of trading goods and/or services (article 2 paragraph (3)) ${ }^{12}$. The brand is used to mark the resulting goods to indicate the origin of the goods (indication of origin). A brand may be regarded as a stamp, mark, spirit, for an item or service. A trademark is any mark or combination of marks capable of distinguishing goods or services from one entity to another. These marks include words, including individual names, letters, numbers, figurative elements, and color combinations, as well as combinations of marks.

Member states may establish registrations based on differences through use if such signs do not sufficiently cause discrepancies in certain goods or services. Even member states can require that the signs be "virtually perceptible". This provision makes it possible to register shapes (shapes), even smells (smells) as Brand.

2. Actual Use: The State may assign registrations 
based on actual use, but the actual use of the Brand should not be used as a condition for registration submissions, in other words, the application for registration should not be rejected solely because the planned use is not carried out before the expiration of the three years from the date of application. This is the basis of national regulation, including Indonesia regarding the right to the Brand to be abolished if not used three years continuously.

3. Nature of Goods: The nature of the goods or services should not be the reason for the rejection of the registration of the Brand.

4. Announcement: The State regulates that before registration, brands are published or announced in advance (article 14) to provide opportunities for other parties wishing to submit objections (disclaimer) to the application for registration of the Trademark as set out in article 16. This provision is the implementation of the principle of openness, as a balance of exclusive rights enjoyed by rights holders.

5. Rights Granted: As in other areas of intellectual property rights, the owner of the Brand has exclusive rights to prevent others, without his permission to use identical (identical) or similar (similar) Brands for trade purposes, and in such case, a likelihood confusion shall be presumed, so the key is identical, similar, and likelihood of confusion.

6. Application Requirements for Obtaining a Brand Certificate: Each party may apply for an official passage of a registered Brand certificate by paying a fee. In the case that the issued Brand certificate is not taken by the owner of the Brand or its Agent within a period of not later than 18 (eighteen) months from the date of issuance of the certificate, the registered Brand shall be deemed withdrawn and abolished.

7. Transfer and License: The right to registered Brand may be transferred or transferred due to inheritance, wills, endowments, grants, agreements, or other reasons justified by law (article 41 paragraph (1)). Registered Brand Owners may grant Licenses to other parties to use the Brand either in part or all types of goods and/or services (article 42). Registered Trademark Owners who have granted licenses to other parties as referred to in Article 42 paragraph (1) may still use themselves or grant licenses to third parties to use the Brand unless otherwise promised.
The State may set the terms of Trademark transfer and the licensor shall be requested to register it with the Minister at a cost. Mandatory licensing has occurred in the United States in the case of Rea Lemon about business competition policy. Defendant company is a company that owns a well-known Brand and controls $75 \%$ of the market for the goods. Parodying with a mandatory license on patents, and to achieve healthy competition in the field of lemon juice order, the Federal Trade Commission (FTC) requires the company to give the Rea Lemon Brand for ten years to others with an open offer to interested parties. The FTC sets royalty at $11 \frac{1}{2} \%$. Apart from this mandatory license, the WTO does not accept the concept.

8. Brand Registration: The Brand cannot be registered if: contrary to state ideology, legislation, morality, religion, decency, or public order; similar to, relating to, or simply mentioning the goods and/or services requested for registration; contains elements that may mislead the public about the origin, quality, type, size, sort, the purpose of use of goods and/or services requested for registration or is the name of protected plant varieties for similar goods and/or services; contain information that is not following the quality, benefits, or efficacy of the goods and/ or services produced; has no differentiating power; and/or; and is a common name and/or publicly owned emblem.

Constitutive principles (important elements) required the registration of a brand for a person or legal entity to obtain legal protection and recognition of the rights to the brand. Registration is carried out at the Directorate General of Intellectual Property Rights through the examination stage until it arrives at the stage of granting rights to the brand in the form of issuance of brand certificates (registered in the General List of Brands). However, the registration of this brand does not escape the possibility of registration without rights made by certain parties who have bad intentions (bad).

Unlicensed registration often occurs in well-known brands because well-known brands are usually attached to a reputation that makes certain parties with bad intentions try to make a profit by dosing or tarnishing the reputation of a well-known brand. This reputation even though intangible is a valuable asset for brand owners as well as for the law so it needs protection.

The registration of this bad-faith brand is often followed by the filing of a lawsuit in the form of 
cancellation of the registration of the brand by the owner of the rights to the original brand. The existence of poor-faith registration and claims of brand cancellation by the original brand owner became the basis for the need to research to see the suitability of the application of the procedure of granting rights to the brand in the Directorate General of Intellectual Property Rights with the brand law governing it.

As it is known that in the business world the main goal is to make a profit, then many industries that do not understand the importance of the relationship between entrepreneurs, consumers, and society will behave profit-oriented solely regardless of other aspects but more concerned with their interests regardless of the interests of the other parties and who encourage them to do so is the availability of consumers who use their products.

Businesses that see it as one of the business opportunities will try to profit through unworthy shortcuts by creating or marketing goods or products by counterfeiting or imitating well-known brands and for consumers is a prestige when using such well-known brands.

Pseudo prestige factor from consumers who feel proud to use well-known brands, especially products from abroad (label minded) is also very affecting and at the same time beneficial for counterfeiting brands, because it gets the opportunity to satisfy the desire of the public through original but fake brands or brands similar to well-known brands, by producing products that are often deliberately tailored to the purchasing power of consumers who want to wear well-known brands but cannot buy them so that they buy original but fake brands as long as they can still prestige. This triggered businesses to make a reputation for selling goods with well-known brands.

The regulation regarding passing off (passing off) in Law Number 20 of 2016 on Brand and Geographical Indication is not yet visible. This is because in Indonesia's literature previously the act of passing off is not widely known either the definition or in detail the description of the form of action. While this is concluded is that passing off is an act of hitchhiking on a well-known brand. In contrast to the common law system countries, such as the United States, United Kingdom, Singapore, Malaysia, or former colonies of the British empire has first known and regulated what is meant by passing off as a form of unfair completion (unfair completion) in the field of trade.

In accommodating the passing off of well-known brands in Indonesia, it is necessary to protect well-known brand rights holders in Indonesia. Such protections are in the form of regulation of laws banning monopoly and unhealthy business competition or antitrust laws or more specifically in the law on brands by the Government of Indonesia. Unfortunately, in Law Number 5 of 1999 on Prohibition of Monopoly and Unhealthy Business Competition the rules on passing off have not yet appeared and are regulated rigidly. The regulation in Law Number 5 of 1999 concerning Prohibition of Monopoly and Unhealthy Business Competition, implies the main point that the existence of antitrust regulations is intended only to ensure that there are adequate clauses on business competition in the market openly or closed on goods or services and prevent a business entity from becoming strong through monopoly practices, monopsony, market mastery, and conspiracy. Therefore, it is necessary to note for the Government of Indonesia in the future so that passing off is regulated also in it.

Related to the act of passing off of a well-known brand is illegal and if the brand that carried out the defection is registered with the Director-General of Intellectual Property will also be rejected because it is considered as a brand that has similarities in essence. The basis of its rejection is contained in Law Number 20 of 2016 on Brand and Geographical Indications, Article 21 paragraph (1), plus paragraph (3) if the registration is done in bad faith

Furthermore, it is also necessary to add to existing laws, among others, philosophical elements at the time of the registration process. The philosophical element is given as the intent of resistance from bad faith. Businesses should be able to give a sign labeling a product as a representation of the reputation of the product. This is done considering that giving a brand name to a product is not easy. Especially when giving a brand name to the creation of his work made with energy, time, mind, and capital that is not a little. Another consideration is that a brand is not allowed to have a multi-interpretation of the understanding of a well-known brand and similarities in essence or its entirety. The law on brand and geographical indications in the future should be able to provide certainty to the Judge about the extent to which a person can provide proof of public knowledge, vigorous promotion of the 
brand, evidenced by anything and not providing a period of limitation of proof of brand registration.

The provisions of Article 21 above actually implied almost the same meaning as the act of passing off on a brand by a business person or business entity. The act of passing off itself is an act that undermines the reputation of a well-known brand. This is because wellknown brands are already known to the general public for goods and or services. Therefore the act of passing off can be analogized as an equality clause in essence. In the old law, this was regulated but clarified again in Law Number 20 of 2016 on Brand and Geographical Indications. However, the law is still unclear in explaining the passing off. Therefore it is expected that the upcoming brand laws regarding the elements of passing off actions, philosophical elements, and the existence of multi-interpretation of well-known brands and similarities in essence or whole can be detailed in detail and clearly.

The use of products with certain brands in addition to the goodwill owned by the brand itself in addition to the fanatical nature of consumers towards the brand is considered to have the advantages or advantages of other brands. The fanatical nature of consumers is not only to meet the needs, but there is also a priority of prestige and gives the impression of the wearer so that by using their perception is a "symbol" that will give rise to a new lifestyle.

There are differences in perceptions in society about brands giving rise to various interpretations, but even so means that the actions of people who produce an item by taking the fame of others can not be justified just like that, because by allowing irresponsible actions it indirectly produces and justifies someone to deceive and enrich themselves dishonestly. The act of using well-known brands owned by others, as a whole is not only detrimental to the owner or holder of the brand itself as well as the consumers but the broader impact is detrimental to the national economy and more broadly also harms international economic relations.

\section{Conclusion}

A drug is an ingredient or alloy of ingredients, including biological products used to influence or investigate the physiological system or state of pathology in the determination of diagnosis, prevention, healing, recovery, improvement of health, and contraceptives for humans. Drug brands in Indonesia are protected by
Law Number 20 of 2016 on Brand and Geographical Indications as a modifier of the old Brand Law (Law Number 19 of 1992 on Brands which was amended into Law Number 14 of 1997 on Brands then changed again to Law Number 15 of 2001 on Brands) has adopted the provisions of TRIPs. Brand laws include brand scope, actual use, nature of goods, announcements, rights granted, application requirements for obtaining brand certificates, transfer and licensing, and brand registration. The politics of the protection of well-known drug brands in the future, that in accommodating the passing off of well-known drug brands in Indonesia, it is necessary to protect holders of well-known brand rights in Indonesia. Such protections are in the form of regulation of laws banning monopoly and unhealthy business competition or antitrust laws or more specifically in the law on brands by the Government of Indonesia. Furthermore, it is also necessary to add to existing laws, among others, philosophical elements at the time of the registration process.

Ethical Clearance: Yes.

\section{Conflict of Interest: No}

Source of Funding: Authors

\section{References}

1. Hananto PWH, Prananda RR. The Urgency Of Geographical Indication As A Legal Protection Instrument Toward Traditional Knowledge In Indonesia. Law Reform. 2019;15(1):62-84. doi: https://doi.org/10.14710/lr.v15i1.23355

2. Luo JB. Protection and Enforcement of WellKnown Mark Rights in China : History, Theory, and Future. Northwestern J Technol Intellect Prop. 2009;7(2):119-161.

3. Putra RA. Legal Possibility To Regulate Defensive Mark As Well-Known Mark Protection In Indonesia. J Intellect Prop. 2018;1(1):1-12.

4. Barizah N. The Development of ASEAN's Intellectual Property Rights Law; from Trips Compliance to Harmonization. Indones Law Rev. 2017;7(1):95-112. https://heinonline.org/HOL/ Page?handle=hein.journals/indolawrev7 \& id=95 $\& \operatorname{div}=\&$ collection $=$.

5. Christiani TA. Normative and Empirical Research Method: Their Usefulness and Relevance in the Study of Law as an Object. In: 3rd Global Conference on Business and Social Science-2015. Vol 219.; 
2016:201-207. doi:10.1016/j.sbspro.2016.05.006

6. Natalis A. The Urgency of the Regional Revenue and Expenditure Budget Implementation Policy in Realizing Women's Welfare. Pandecta. 2020;15(1):79-88.

7. Asra R, Zulharmita, Yuliatim N. Determination of Dexamethasone in Unregistered Herbal Weight Gain Using HPTLC-Densitometry. Indones J Pharm Clin Res. 2018;1(2):21-28. doi:10.32734/ idjpcr.v1i2.331

8. Magdariza, Enggriyeni D. The Juridical Review Of Law Amandement of Brand And Geographic Indication In Trading Liberalization Of ASEAN And The Influence To Indonesia. In: Proceeding Of The 1st International Conference On Asean (ICASEAN).; 2019:266-233.
9. Noor NAM, Aziz ASA. Copyright Legal Issues In Malaysian Esport Industry. In: Selected Legal Issues in Indonesia And Malaysia.; 2019:51-63.

10. Rustamaji M. Control Measure Granting Legal Aid Views Of Richard A Posner. Rechtsvinding. 2013;2(1):95-106.

11. Hough M, Jackson J, Bradford B, Myhill A, Quinton P. Procedural Justice, Trust, and Institutional Legitimacy. Policing. 2010; 4(203-210):1-8. doi:10.1093/police/paq027

12. Suryahartati D. Commercialization and Management of Higher Education Research Results In The Industrial Age 4.0: Intellectual Property Rights Perspective. IPR-Review. 2019;2(2):127135. 